\title{
Procedural Autonomy of a Member State: Application of the Principle by Latvian Administrative Courts
}

\author{
Dr. iur. Jautrīte Briede \\ Faculty of Law, University of Latvia Professor at the Department of Public Law \\ E-mail:briede@lu.lv
}

The article addresses certain issues of principle of national procedural autonomy. The meaning of the principle is briefly explained at the beginning of the article. It is followed by analyses of examples of the application of this principle by Latvian courts after the judgments of Court of Justice of the European Union, as well application of the principle of procedural autonomy by Latvian courts on their own initiative.

Keywords: national procedural autonomy, the principle of effectiveness.

\section{Contents}

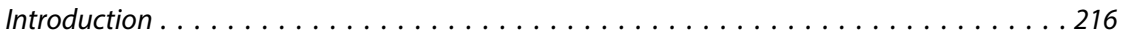

1. The Meaning of the Principle of Procedural Autonomy . . . . . . . . . . . . . . 217

2. Application of the Principle of Procedural Autonomy

by Latvian Courts After the Judgement of CJEU . . . . . . . . . . . . . . . . 218

3. Application of the Principle of Procedural Autonomy by Latvian Courts on Their Own Initiative . . . . . . . . . . . . . . . . . . . . . . 220

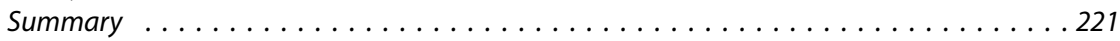

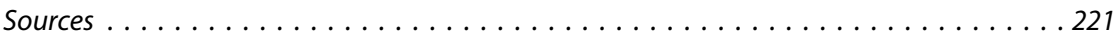

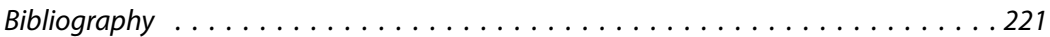

Normative Acts . . . . . . . . . . . . . . . . . . . . . . . 2222

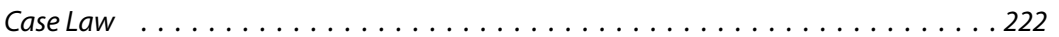

\section{Introduction}

Within the European Union (EU), many articles and even monographs are devoted to the principle of procedural autonomy of a Member State. At the same time, the principle is mentioned in the Latvian legal literature only in general ${ }^{1}$, but there are no separate articles or studies on this issue. To fill this gap, the current article will view some aspects of this principle. ${ }^{2}$

1 For example: Gailìtis, K., Potaičuks, A. Eiropas Savienības tiesības. I daḷ. Institucionālās tiesības [Law of European Union. I Part. Institutional Law]. $2^{\text {nd }}$ supplemented edition. Gailitis, K., Buka, A., Schewe, C. (scient. eds.). Rīga: Tiesu namu aǵentūra, 2019, pp. 274-275.

2 Some aspects are also discussed in the report of this author at the $79^{\text {th }}$ International Scientific Conference of the University of Latvia. 
The meaning of the principle will be briefly explained at the beginning of the article.

As commentators have pointed out, because the array of procedural rules is vast and diversified throughout administrative, civil and criminal law, it comes as no surprise that the actual scope of procedural autonomy significantly differs from one issue to another. ${ }^{3}$ A synthesis of the case law indicates that the qualifications of equivalence and effectiveness, which are the criteria for applying this principle, have become powerful doctrinal tools directing national courts to undertake a case-bycase appraisal of national rules. ${ }^{4}$

Taking this into account, application of the principle of procedural autonomy by the Latvian Supreme Court will be analysed through the prism of findings of the Court of Justice of the European Union (CJEU). The case where the court has applied the principle of effectiveness arising from the principle of procedural autonomy of its own motion will also be considered.

It should also be noted that the reasoning delivered in proceedings before an administrative court quite clearly also applies to references by civil courts. ${ }^{5}$ Thus, the findings formulated in this article in connection with examples from administrative law mutatis mutandis also apply to civil and criminal procedure.

\section{The Meaning of the Principle of Procedural Autonomy}

The principle of national procedural autonomy stipulates that the Member States are free to set up their own (procedural) rules (and remedies therein) which govern the enforcement of European Union Law.

However, the CJEU has repeatedly stated: it is apparent from the Court's settled case law that, in the absence of EU rules governing the matter, it is a discretion of each Member State to prescribe detailed rules in respect of administrative and judicial procedures, which cover the probative value of a document, intended to safeguard the rights which individuals derive from EU law, in accordance with the principles of equivalence and effectiveness (see, to that effect, judgments of 16 December 1976, Rewe-Zentralfinanz and Rewe-Zentral, 33/76, EU:C:1976:188, paragraph 5, and of 26 June 2019, Craeynest and Others, C-723/17, EU:C:2019:533, paragraph 54), without undermining the effectiveness of EU. ${ }^{6}$

Consequently, the Member States do not have complete autonomy, since they are (primarily) limited by the principle of effectiveness and the principle of equivalence. ${ }^{7}$

Commentators have drawn attention to the fact that in the early CJEU case law the principle was qualified by two requirements: that conditions laid down by national law should be applied in the same way (equivalence) and that they should not render the exercise of EU rights impossible in practice (practical possibility). Over the time, CJEU began to emphasize stronger notions of adequacy and

3 Baghrizahebi, D. The Current State of National Procedural Autonomy: A Principle in Motion. 3 Inter EU Law East: J. Int'l \& Eur. L., Econ. \& Market Integrations, No. 13, 2016, p. 13.

4 Craig, P., De Búrca, G. EU Law. Text, cases, and materials. $3^{\text {rd }}$ edition. Oxford: Oxford University Press, 2003, p. 230.

5 See Wallerman, A. The Impact of EU Law on Civil Procedure. Gothenburg University Publications. Tidschrijft voor Civiele Rechtspleging, No. 3, 2013, p. 3. ISSN 0929-8649). Available: https:/gup.ub.gu. se/file/206874 [last viewed 31.01.2021].

6 The Court of Justice of the European Union judgment of 2 April 2020 in case No. C-480/18 PrivatBank. para. 73. Available: http://curia.europa.eu/ [last viewed 31.01.2021].

7 Baghrizahebi, D. The Current State ..., p. 13. 
effectiveness, rather than merely practical possibility, in the domestic enforcement of EU law. The CJEU also sometimes required national courts to make available a particular type of remedy (reparation, interim relief etc.) regardless of whether or not this would be available under national law. ${ }^{8}$ Many commentators underscore the fact that it is mainly the principle of effectiveness that is invoked in the CJEU's jurisprudence; equivalence is much less exploited. ${ }^{9}$

Some authors have pointed out that it is clear that a certain tension exists between the principle of primacy and the principle of national procedural autonomy: the obligation to set aside rules of national procedural law is diametrically opposed to the principle of national procedural autonomy. Hence, it is not surprising that the Court of Justice generally opts for one of these two principles as starting point when answering preliminary questions on collisions between EU law and national law. Whereas the principle of primacy has a hierarchical character, the principle of national procedural autonomy leaves more room for assessment, as it does not by definition require that the national rule which hinders the effectiveness of EU law has to be set aside. Although the primacy of EU law over national law is a generally applicable principle, its use only leads to a solution when a direct collision is concerned. ${ }^{10}$

However, this could be disputed, because the principle of procedural autonomy includes the principle of efficiency, they do not conflict with each other, but complement each other.

Legislations of Member States reviewed by the CJEU mostly concern the following aspects: access to a court or tribunal; the scope of judicial review; the right of the defence; time limits and remedies. Commentators have pointed out that, in all of these categories, in spite of procedural autonomy, many national rules were condemned, or, if not, very precise indications were given to the State concerned on the conditions under which its legislation would comply with the EU right to judicial protection. ${ }^{11}$ Such a tendency is not represented in Latvian cases.

\section{Application of the Principle of Procedural Autonomy by Latvian Courts After the Judgement of CJEU}

The CJEU case law database indicates three Latvian cases in which the principle of procedural autonomy is explicitly mentioned: C-541/14 VM Remonts ${ }^{12}$, C-46/16 LS Customs Services ${ }^{13}$ and C-480/18 PivatBank ${ }^{14}$.

In the case VM Remonts, the Latvian court asked whether an undertaking may be held liable for a concerted practice on account of the acts of an independent service provider supplying it with services. In the judgement of the CJEU, the

Craig, P., De Búrca, G. EU Law, p. 230.

9 Kowalik-Bańczyk, K. Procedural Autonomy of Member States and the EU Rights of Defence in Antitrust Proceedings. Yearbook of Antitrust and Regulatory Studies, Vol. 5(6), 2012, p. 220.

10 Ortlep, R., Verhoeven, M. The Principle of Primacy versus the Principle of National Procedural Autonomy. NALL, juni 2012. DOI: 10.5553/NALL/.000004

11 Giubboni, S., Robin-Oliver, S. Analytical Report 2016. Effective Judicial Protection in the Framework of Directive 2014/54/EU. European Commission. Brussels: FreSsco, 2016, p. 8.

12 The Court of Justice of the European Union judgment of 21 July 2019 in case No. C-541/14. VM Remonts. Available: http://curia.europa.eu/ [last viewed 31.01.2021].

13 The Court of Justice of the European Union judgment of 9 November 2017 in case No. C-46/16. Available: http://curia.europa.eu/ [last viewed 31.01.2021].

14 The Court of Justice of the European Union judgment of 2 April 2020 in case No. C-480/18. Available: http://curia.europa.eu/ [last viewed 31.01.2021]. 
principle of procedural autonomy was mentioned only in passing, indicating that the assessment of evidence and the requisite standard of proof, in the absence of EU rules on the matter, are covered, in principle, by the procedural autonomy of the Member States.

In the other two cases, the principle of procedural autonomy or at least the principle of effectiveness (as a criterion for the application of the above principle) are mentioned to in the operative part of the CJEU judgments.

In the LS Customs Services case, the Latvian court, inter alia, asked about the significance of the duty to state reasons and the effect of shortcomings in the reasoning of the decision of the customs authority.

As it was pointed out by the Advocate General, the question of the duty to state reasons incumbent on national customs authorities must, however, be distinguished from the question of the legal consequences in national law of an inadequate statement of reasons and thus from the question whether it is possible to remedy defective reasoning in the course of legal proceedings. This question is not regulated by the Customs Code and EU law does not contain general rules elsewhere on the consequences of defective reasoning. It is therefore for the Member States, exercising their procedural autonomy, to regulate the consequences of a failure by the customs authorities to fulfil their duty to state reasons and to determine whether and to what extent it is possible to remedy such a failure in the course of legal proceedings. In doing so, however, the Member States must have regard to the principles of equivalence and effectiveness. ${ }^{15}$

The CJEU, agreeing with the Advocate General's Opinion, stated in the judgment that it was for the Member States, exercising their procedural autonomy, to regulate the consequences of a failure by the customs authorities to fulfil their obligation to state reasons and to determine whether and to what extent such a failure may be remedied in the course of legal proceedings, subject to observance of the principles of equivalence and effectiveness.

Neither that answer nor the judgment as a whole indicates that the principle of effectiveness takes precedence over the obligation to state reasons. There are only indications that the principle of efficiency must also be taken into account.

Nevertheless, in deciding the case after receiving the judgment of the CJEU, the Supreme Court of Latvia did not focus on the analysis of the principle of effectiveness at all. It decided the case solely on the ground of breach of the obligation to state reasons. ${ }^{16}$

It is likely that such an analysis would not change the outcome of the proceedings, but it would be highly desirable to show that the principle of effectiveness is taken into account. In the case, it was clear that the principle of the effectiveness of EU law and the obligation to state reasons ${ }^{17}$ were in conflict. In such a case, the conflicting principles must be weighed up and the reasons given why the

15 Opinion of Advocate General Kokott delivered on 30 March 2017 in case No. C-46/16, para. 84-85. Available: http://curia.europa.eu/ [last viewed 31.01.2021].

16 Republic of Latvia Supreme Court judgment of 16 June 2018 in case No. SKA-4/2018. Available: www. at.gov.lv [last viewed 20.03.2021].

17 Statement of reasons is indicated as one of procedural principles of administrative law in Council of Europe Resolution (77)31 on the protection of the individuals in relation to the acts of administrative authorities. (Adopted by the Committee of Ministers on 28 September 1977 at the $275^{\text {th }}$ meeting of the Ministers' Deputies). Available: https://rm.coe.int/16804dec56 [last viewed 20.03.2021]. 
particular principle is being preferred. ${ }^{18}$ Otherwise, one may think that the court has considered the principle of effectiveness to be irrelevant.

In this respect, the judgment of the Supreme Court of Latvia in the case of PivatBank is the opposite: the Latvian Supreme Court referred the question to the CJEU whether in carrying out the supervisory functions or in conducting the complaint procedures provided for in EU law, must the competent authority take account of an arbitration decision settling a dispute between a payment service provider and a payment service user. The CJEU gave the answer that in accordance with the principle of the procedural autonomy of the Member States, the national legislature may give the competent authority the power to take into account the existence and contents of an arbitration ruling settling a dispute, provided that the probative value given to that ruling in those procedures is not liable to undermine the purpose or specific objectives of the procedures, the rights of defence of the persons concerned or the independent exercise of the powers and competencies conferred on that authority, which is a matter for the referring court to ascertain.

Deciding the case after receiving the judgment of the CJEU, the Supreme Court of Latvia carefully analysed whether the principle of effectiveness would be respected if it took into account the arbitration decision. The Senate has argued that arbitration decisions are not subject to the kind of mechanisms that ensure the full effectiveness of EU law (the arbitration decision is not obliged to apply to the CJEU). Consequently, the court cannot be bound by the assessment of the factual and legal circumstances of the case expressed in the arbitration decision, otherwise it would be obliged to rely on the interpretation of the ruling and its provisions, which the issuing authority is not entitled to appeal to the CJEU. ${ }^{19}$

It follows from the motivation of the judgment that the principle of effectiveness has been the ratio decidendi in the judgment of the Supreme Court regarding the arbitration decision as evidence in the case.

\section{Application of the Principle of Procedural Autonomy by Latvian Courts on Their Own Initiative}

The application of EU law is becoming more and more commonplace in Latvian administrative courts. In most cases, procedural issues of application of EU law are not regulated at the level of EU, therefore public authorities and administrative courts apply the provisions of the Administrative Procedure Law ${ }^{20}$. It also means that the courts apply the principle of procedural autonomy, however, usually they do not mention the principle expressis verbis in their rulings.

Nevertheless, there is a judgment in which the Supreme Court of Latvia has applied the principle of effectiveness of EU law and referred to the principle of procedural autonomy. That was done because these principles played a substantial role in deciding the case.

18 Iljanova, D. Tiesību normu un principu kolīzija [Conflict of legal norms and principles]. Likums un Tiesības, Vol. 2, No. 8, 2000, p. 251.

19 Republic of Latvia Supreme Court judgment of 29 January 2021 in case No. SKA-07/2021. Judgment is not available. A press release on the judgement is available: https://vportals.lv/dienaskartiba/324512atstaj-speka-finansu-un-kapitala-tirgus-komisijas-lemumu-par-bankai-uzliktu-soda-naudu-2021 [last viewed 31.01.2021].

20 Administratīvā procesa likums [Administrative Procedure Law]. Available: https://likumi.lv/ta/ id/55567-administrativa-procesa-likums [last viewed 20.03.2021]. 
In the case, the railway undertaking had applied to the administrative court for a safety certificate which would allow it to operate transport services from the boarder station to the national border. The State Railway Technical Inspectorate considered that, in order to avoid safety risks, the applicant should first enter into an agreement with the Belarusian Railways. A situation had arisen because the applicant was denied a certificate until it presented a cooperation agreement with the Belarusian Railways, while Belarusian Railways refused to conclude a cooperation agreement until the applicant was granted a safety certificate allowing access to the railway infrastructure up to the Latvian-Belarusian border.

The Supreme Court concluded that the EU law relevant to the case required active involvement of the state in resolving the issues of cross-border railway traffic organization, but the Latvian legislator had not clearly and precisely regulated this obligation in regulatory enactments. As a result, the applicant was not guaranteed the rights it enjoyed under EU law and this undermined the practical effect of EU law.

Therefore, referring also to the limits of the principle of procedural autonomy, the Supreme Court concluded that the regional court in this case should not confine itself to concluding that the absence of a cooperation agreement with the Belarusian Railways was a factual obstacle to the issuance of a safety certificate. The Supreme Court noted that in order to ensure the effectiveness of EU law, the regional court had to seek a legal remedy to help the applicant to break out of the "vicious circle". The Supreme Court also indicated possible remedies. ${ }^{21}$

Thereby, in this case the principle of effectiveness, which limits the principle of procedural autonomy, has served as the ratio decedendi for deciding the case.

\section{Summary}

Although the application of the principle of procedural autonomy in Latvian administrative court practice has become commonplace, there are not many court rulings in which the principle is mentioned in the text and where it would have been decisive for deciding the case. There are few judgments where the application of the principle of effectiveness is the ratio decidendi of a case.

There are also few cases which have been dealt with after the court has referred preliminary questions to the CJEU and received answers. From these judgments, it can be concluded that the courts do not always pay due attention to the principle of efficiency which should be applied within the procedural autonomy. Where the principle of effectiveness of EU law conflicts with another principle of law, they must be weighed against each other and the choice made between them must be justified in the judgment.

\section{Sources}

\section{Bibliography}

1. Administratīvā procesa likuma komentāri. A un B daḷa [Comments upon Administrative Procedure Law. Parts A and B]. Collective of authors, scientific ed. Dr. iur. Briede, J. Rīga: Tiesu namu agentūra, 2013.

2. Baghrizahebi, D. The Current State of National Procedural Autonomy: A Principle in Motion. 3 Inter EU Law East: J. Int'l \& Eur. L., Econ. \& Market Integrations, No. 13, 2016.

21 Republic of Latvia Supreme Court judgment of 19 March 2021 in case No. SKA-389/2021. Available: https://manas.tiesas.lv/eTiesasMvc/lv/nolemumi [last viewed 20.03.2021]. 
3. Biernat, S., Piłaszewicz-Kulikowska, M., Wilk, A., Florjanowicz-Błachut, P., Wróbel, P. Consequences of Incompatibility with EC Law for Final Administrative Decisions and Final Judgements of Administrative Courts in the Member States. Warszawa: Naczelny Sąd Administracyjny, 2008.

4. Craig, P., De Búrca, G. EU Law. Text, Cases, and Materials. $3^{\text {rd }}$ edition. Oxford: Oxford University Press, 2003.

5. Gailītis, K., Potaičuks, A. Eiropas Savienības tiesības. I daḷa. Institucionālās tiesības [Law of European Union. I Part. Institutional Law]. $2^{\text {nd }}$ supplemented edition. Gailitis, K., Buka, A., Schewe, C. (scient. eds.). Rīga: Tiesu namu aǵentūra, 2019.

6. Giubboni, S., Robin-Oliver, S. Analytical Report 2016. Effective Judicial Protection in the Framework of Directive 2014/54/EU. European Commission. Brussels: FreSsco, 2016.

7. Iljanova, D. Tiesību normu un principu kolīzija [Conflict of legal norms and principles]. Likums un Tiesības, Vol. 2, No. 8, 2000.

8. Kowalik-Bańczyk, K. Procedural Autonomy of Member States and the EU Rights of Defence in Antitrust Proceedings. Yearbook of Antitrust and Regulatory Studies, Vol. 5(6), 2012.

9. Ortlep, R., Verhoeven, M. The Principle of Primacy versus the Principle of National Procedural Autonomy. NALL, juni 2012. DOI: 10.5553/NALL/.000004

10. Wallerman, A. The Impact of EU Law on Civil Procedure. Gothenburg University Publications. Tidschrijft voor Civiele Rechtspleging, No. 3, 2013. ISSN 0929-8649. Available: https://gup.ub.gu.se/ file/206874 [last viewed 31.01.2021].

\section{Normative Acts}

1. Administratīvā procesa likums [Administrative Procedure Law]. Available: https://likumi.lv/ta/ $\mathrm{id} / 55567$-administrativa-procesa-likums [last viewed 20.03.2021].

2. Resolution (77)31 on the protection of the individuals in relation to the acts of administrative authorities. (Adopted by the Committee of Ministers on 28 September 1977 at the $275^{\text {th }}$ meeting of the Ministers' Deputies). Available: https://rm.coe.int/16804dec56 [last viewed 20.03.2021].

\section{Case Law}

\section{The European Court of Justice}

1. The Court of Justice of the European Union judgment of 21 July 2019 in case No. C-541/14. VM Remonts. Available: http://curia.europa.eu/ [last viewed 31.01.2021].

2. The Court of Justice of the European Union judgment of 9 November 2017 in case No. C-46/16. LS Customs Services. Available: http://curia.europa.eu/ [last viewed 31.01.2021].

3. The Court of Justice of the European Union judgment of 2 April 2020 in case No. C-480/18. PrivatBank. Available: http://curia.europa.eu/ [last viewed 31.01.2021].

4. Opinion of Advocate General Kokott delivered on 30 March 2017 in case No. C-46/16, para. 84-85. Available: http://curia.europa.eu/ [last viewed 31.01.2021].

\section{Judgments of Administrative Courts}

5. Republic of Latvia Supreme Court judgment of 16 June 2018 in case No. SKA-4/2018. Available: www.at.gov.lv [last viewed 20.03.2021].

6. Republic of Latvia Supreme Court judgment of 29 January 2021 in case No. SKA-07/2021. A press release on the judgement is available: https://vportals.lv/dienaskartiba/324512-atstaj-spekafinansu-un-kapitala-tirgus-komisijas-lemumu-par-bankai-uzliktu-soda-naudu-2021 [last viewed 31.01.2021].

7. Republic of Latvia Supreme Court judgment of 19 March 2021 in case No. SKA-389/2021. Available: https://manas.tiesas.lv/eTiesasMvc/lv/nolemumi [last viewed 20.03.2021]. 